\title{
Symbiotic relations between bacteria and the domoic acid producing diatom Pseudo-nitzschia multiseries and the capacity of these bacteria for gluconic acid/gluconolactone formation
}

\author{
James E. Stewart*, L. J. Marks, C. R. Wood, S. M. Risser, S. Gray \\ Marine Environmental Sciences Division, Science Branch, Department of Fisheries and Oceans, \\ Bedford Institute of Oceanography, PO Box 1006, Dartmouth, Nova Scotia, Canada B2Y 4A2
}

\begin{abstract}
Bacteria isolated from cultures of 4 different strains of the diatom Pseudo-nitzschia multiseries following numerous transfers in a defined medium were identified as mainly Moraxella and Alteromonas $\mathrm{sp}$. These bacteria apparently form a characteristic suite of microorganisms living in a symbiotic relationship with the diatom. The bacterial isolates from each of the $P$. multiseries strains divided metabolically into 2 groups; those that produced significant amounts of acid from carbohydrates and those that grew readily at the expense of amino acids. The specific acid forming bacteria isolated from each diatom species grown in the presence of glucose produced gluconic acid/gluconolactone in quantity and released it to the surrounding medium. For growth of the diatom a salinity of $33 \mathrm{ppt}$ was more favorable than 26 or $38 \mathrm{ppt}$; sorbitol varied with the salinity and thus might be an osmolyte. Glucose was present in significant quantities in the diatom grown at all 3 salinities. Nonaxenic growth of the diatom was stimulated considerably by the presence of proline alone and to approximately the same level when it was combined with glucose or sodium acetate, but not when glycine was substituted for the proline. Stimulation of the growth of the diatom by the presence of proline was considered to be a function of the associated bacteria. Glycine combined with sodium acetate was slightly inhibitory to the growth of the diatom but both glycine plus sodium acetate and glycine plus glucose combinations were markedly inhibitory to the growth of the associated bacteria. The possible role of all of these features in the initiation of a bloom of Pseudo-nitzschia multiseries, especially in an inshore environment enriched by organic nitrogen, and the consequent production of domolc acid is discussed.
\end{abstract}

KEY WORDS: Symbiosis - Domoic acid Diatom - Pseudo-nitzschia multiseries - Gluconic acid/ gluconolactone $\cdot$ Salinity $\cdot$ Bacteria

\section{INTRODUCTION}

In 1987, the consumption of mussels cultured in the tidal Cardigan River and estuary in Prince Edward Island (PEI, Canada) that were contaminated with high levels of the neurotoxin domoic acid resulted in widespread intoxication and several deaths (Bird et al 1988, Subba Rao et al. 1988b, Bates et al. 1989, Wright et al. 1989, Perl et al. 1990, Todd 1990, 1993). The

•E-mail: james.stewart@maritimes.dfo.ca domoic acid was produced by the diatom identified at that time as Nitzschia pungens and now renamed Pseudo-nitzschia multiseries (Hasle 1995) which had bloomed in the Cardigan River and estuary and which formed, in November 1987, the predominant food of the mussels cultured there

Following the intoxication episode, McLachlan et al. (1993) demonstrated, by ion mobility spectrometry (IMS) and mass spectrometry, the presence of gluconolactone in the untreated fluid of only those mussels shown by high performance liquid chromatography (HPLC) to contain domoic acid. In solution, gluconolac- 
tone actually exists as an equilibrated mixture composed of gluconic acid, a powerful sequestering agent, and the delta and gamma lactones (Merck Index; Windholz 1983), and thus should be referred to as the mixture gluconic acid/gluconolactone rather than as a single compound. Through collaborative work with one of us (J.E.S.), D. G. McLachlan \& A. H. Lawrence (unpubl.) showed that an extract of a bacterium isolated from close association with Pseudo-nitzschia multiseries contained a compound similar to gluconolactone; they did not find it, however, in extracts of $P$. multiseries (D. V. Subba Rao pers. comm.). In an expansion of this work, Osada \& Stewart (1997, in this issue) exposed $P$. multiseries cultures (axenic and those made non-axenic with selected bacteria) to gluconic acid/gluconolactone which resulted in marked incrcases in domoic acid production by the diatom; the effect was concentration dependent. The presence of glutamate or proline in equivalent concentrations had a repressive effect on the influence of gluconic acid/gluconolactone.

As the gluconic acid/gluconolactone in mussel fluids could have been produced by bacteria closely associated with the diatom, we undertook to isolate and characterize, from Pseudo-nitzschia multiseries cultures, bacteria which had endured with the diatom over a number of transfers, to examine these for their capacity to produce acids from likely carbohydrates, and to determine those which formed gluconic acid/gluconolactone and the quantities produced. In addition we examined the diatom as a possible source of carbohydrate(s) and measured the growth of the diatom in different salinities and in the presence of various organic additives of the kind and quantity that might have been contributed by run-off waters to the Cardigan estuary.

\section{MATERIALS AND METHODS}

Diatoms. The 4 diatom isolates used as sources for the bacteria and in other aspects of this study were characterized at the time of their isolation variously as Nitzschia pungens, $N$. pungens f. pungens or $N$. pungens f. multiseries. These diatom cultures are shown in Table 1.
Subsequently strains $\mathrm{N}$ and $\mathrm{NpH}$ have been identified as Pseudo-nitzschia multiseries (Pan et al. 1996 and K. E. Pauley pers. comm. respectively) according to the criteria of Hasle (1995). The NRO strain was originally listed as a non-producer of domoic acid; however, subsequent testing with the highly sensitive ELISA technique (Osada et al. 1995) showed the presence of a small amount of domoic acid. This suggests that the NRO strain was, in fact, also a $P$. multiseries strain, albeit a minimal producer of domoic acid. Strain NpD was identified as a Pseudo-nitzschia sp. (Subba Rao pers. comm.).

Al.l diatom cultures were maintained in liquid medium which was a modification of that proposed by Harrison et al. (1980); the steam-sterilized trace metals and nutrients (minus the siilate anu buic acid, and with $\mathrm{NaH}_{2} \mathrm{PO}_{4}$ substituted for glycerophosphate) were added aseptically to natural seawater filtered first through a $0.22 \mu \mathrm{m}$ membrane and then steam sterilized (the seawater was taken from bulk supplies collected from Bedford Basin in the fall of 1990, passed through a $53 \mu \mathrm{m}$ pore size filter and stored unsterilized in closed containers at room temperature for later use) followed by the aseptic addition of the vitamin mixture and $1 \mathrm{ml} \mathrm{l}^{-1}(0.035 \mathrm{~g})$ of a $\mathrm{Na}_{2} \mathrm{SiO}_{3} \cdot 9 \mathrm{H}_{2} \mathrm{O}$ sterile solution to give a final silicate concentration of $0.123 \mathrm{mM}$. Additives for growth experiments, i.e. glycine, sodium acetate, glucose and proline, were steam sterilized separately as $10 \mathrm{M}$ solutions and added aseptically to $1500 \mathrm{ml}$ of the basal diatom medium in Fernbach flasks to give final concentrations of $22 \mathrm{mM}$ each. Although these concentrations are much higher than found in open ocean waters, they are comparable to concentrations used successfully for similar studies (Liu \& Hellebust 1974 a, b. Schobert 1980) and values for organic nitrogen for nutrified inshore environments are higher than those in open ocean waters. The generally higher level of nutrients in the Cardigan area for late 1987 and early 1988 was shown by Subba Rao et al. (1988a) who carried out detailed measurements of nutrients and phytoplankton populations. All diatom cultures were incubated in a continuous cool-white fluorescent light regime measuring around $170 \pm 30 \mu \mathrm{mol} \mathrm{m} \mathrm{m}^{-2} \mathrm{~s}^{-1}$ (QSL light meter, Biospherical Instruments Inc.) at $10^{\circ} \mathrm{C}$

Table 1. Diatom isolates used as sources in this study

\begin{tabular}{|llllll|}
\hline $\begin{array}{l}\text { Laboratory } \\
\text { identifier }\end{array}$ & \multicolumn{1}{c}{ Isolator } & \multicolumn{1}{c}{ Source } & $\begin{array}{c}\text { Isolation } \\
\text { date }\end{array}$ & $\begin{array}{c}\text { Isolator's } \\
\text { identifier }\end{array}$ & $\begin{array}{c}\text { Domoic acid } \\
\text { producer }\end{array}$ \\
\hline $\mathrm{N}$ & D. V. Subba Rao & Cardigan River, PEI & Dec 1987 & NPBIO & Positive/HPLC \\
$\mathrm{NpD}$ & D. V. Subba Rao & Digby, Nova Scotia & Oct 1991 & \#301 & Not tested \\
$\mathrm{NRO}$ & C. Légere & Brudenell River, PEI & Aug 24, 1989 & (Brud. C) & Trace/ELISA \\
$\mathrm{NpH}$ & K. E. Pauley & New London Bay, PEI & Oct 18, 1991 & K.P. 59 & Positive/HPLC/ELISA \\
\hline
\end{tabular}


except for the strain $\mathrm{NpH}$ which was grown throughout at $20^{\circ} \mathrm{C}$.

The salinity of the standard diatom medium was approximately 33 parts per thousand (ppt). For the determination of the effect of salinity change on growth and carbohydrate content of the Pseudo-nitzschia multiseries strain $\mathrm{NpH}$, the salinity was increased by the addition of $\mathrm{NaCl}$ to give 38 ppt or decreased by the addition of distilled water to give $26 \mathrm{ppt}$. Growth curves were determined with these media at $20^{\circ} \mathrm{C}$ in still culture and diatom cells were harvested at appropriate times by centrifugation $(2000 \times \mathrm{g}$ for $10 \mathrm{~min})$. The culture filtrates were decanted and the cell pellets were resuspended in distilled water; the cells were ruptured by treatment with a Sonic Dismembrator 300 (Artek System Corporation) equipped with a titanium microtip and operated at 35\% maximum power (ca $100 \mathrm{~W}$ ). The resulting homogenates were centrifuged $(10000 \times g$ for $10 \mathrm{~min})$ to remove debris; the supernatant fluids were decanted, frozen and stored at $-10^{\circ} \mathrm{C}$ for subsequent analysis for glucose, fructose, mannose and sorbitol.

Diatom numbers were determined by direct microscopic counts on samples removed from the growth flasks, mixed with fixative (1:1 formalin:glacial acetic acid) at $2 \%$ final concentration and settled in glassbottomed plankton counting chambers. Alternatively, certain of the diatom growth curves were constructed using a Coulter Counter Model TA II (Coulter Electronics Inc., Hialeah, FL) on diatom culture suspensions exposed first to mild sonic treatment using an Ultrasonik Model $20 \mathrm{~T}$ (Ultrasonic Ney, Barkmeyer Division, Yucaipa, CA) just sufficient to disrupt the chains (ca 5 min exposure) diluted when necessary with sterile natural seawater.

Isolation of bacteria associated with the diatoms. Following repeated (between 6 and 10) transfers of the diatom cultures at 2 wk intervals, loopfuls of the culture fluids were streaked on Marine Agar plates (Difco \#2216) that were incubated at $20^{\circ} \mathrm{C}$ as for all isolation procedures. The resulting bacterial growth was followed over the course of $1 \mathrm{wk}$ and all colonies with different appearances were picked into Marine Broth (Difco \#2216); subsequently these were re-streaked on Marine Agar plates to ensure purity; the different strains were assigned working designations consisting of the laboratory identifier letters of the Pseudonitzschia multiseries strain from which the bacteria were isolated plus an isolate number, e.g. bacterial strains $\mathrm{N} 7$ and $\mathrm{N} 9$ were isolated from $P$. multiseries strain $N$. The bacterial isolates were maintained on Marine Agar slants for further study.

Identification of bacteria. The bacteria isolated from association with the diatoms were subjected to a battery of microbial procedures for identification fol- lowing the scheme modified by Austin (1988) from the original proposed by Austin (1982) for identification of aerobic, heterotrophic bacteria from a coastal marine environment. With certain exceptions the tests done to provide the data for the Austin scheme followed the multidish methodology described by Hansen \& Sorheim (1991) for identification of marine bacteria. The exceptions, additions or modifications were: (1) motility, oxidation and fermentation determinations used the Modified Oxidation/Fermentation Medium of Walters \& Plumb (1978) brought to $1.5 \% \mathrm{NaCl}_{i}$ (2) catalase was determined using $3 \% \mathrm{H}_{2} \mathrm{O}_{2}$ in a black microwell plate in which agar-grown bacteria were immersed; (3) requirement for $\mathrm{Na}^{+}$was determined using the medium of MacLeod (1968) in which $\mathrm{Na}^{+}$was replaced by equimolar amounts of $\mathrm{K}^{+}$(4) casein hydrolysis was determined with $1 \%$ casein added to Marine Agar and clearing was confirmed by flooding the multidish with $10 \% \mathrm{HCl}$ at the end of the incubation period; (5) indole was determined using Marine Agar plus 1\% Bactotryptone and after $4 \mathrm{~d}$ incubation, flooding with Kovac's reagent as in Hansen \& Sorheim (1991); (6) arginine decarboxylase was measured using BactoDecarboxylase Base Medium plus $2 \% \mathrm{NaCl}$ and $1 \%$ arginine; (7) cytochrome oxidase was determined with Pathotec Cytochrome Oxidase strips following the manufacturer's directions (Organon Teknika Corp., Durham, NC); and (8) penicillin sensitivity was determined with Difco Penicillin G Dispens-O-Discs $\left(10\right.$ units disc $\left.{ }^{-1}\right)$.

Bacterial growth studies. For the determination of growth with amino acids the basal medium consisted of artificial seawater salts composed of $\mathrm{CaCl}_{2} \cdot 2 \mathrm{H}_{2} \mathrm{O}$, $2 \mathrm{~g}, \mathrm{MgSO}_{4} \cdot 7 \mathrm{H}_{2} 0,14.3 \mathrm{~g}, \mathrm{NaCl}, 21.5 \mathrm{~g}, \mathrm{KCl}, 1.5 \mathrm{~g}$, plus trace elements, $10 \mathrm{ml}$ (the same mixture as used for the diatom cultures; Harrison et al. 1980), to this was added yeast extract (Difco), $0.5 \mathrm{~g}$, amino acid, $2 \mathrm{~g}$, distilled watcr, $1000 \mathrm{ml}$, and the solution was adjusted to a final $\mathrm{pH}$ of 7.6 . The amino acids glycine, L-alanine, L-leucine, L-isoleucine, L-glutamic acid and L-proline were obtained from the Sigma Chemical Co., St. Louis, $\mathrm{MO}$. The medium was dispensed in $10 \mathrm{ml}$ quantities in $15 \mathrm{~mm}$ diameter culture tubes and steam sterilized. Duplicate tubes were inoculated with $50 \mu \mathrm{l}$ each of a $48 \mathrm{~h}$ Marine Broth culture and incubated at $20^{\circ} \mathrm{C}$. Growth was determined by recording the changes in absorbance measured at $540 \mathrm{nM}$ using a Spectronic 20 series spectrophotometer (Milton Roy Company, Rochester, NY). Growth of bacteria in association with the diatom was determined using Marine Agar for the drop plate count method of Miles \& Misra (1938); appropriate dilutions were made with sterile $3 \% \mathrm{NaCl}$ as the diluent.

Acid from carbohydrates. Qualitative: The basal medium was Marine Broth to which glucose, sorbitol, 
mannose or mannitol (Sigma Chemical Co.) was added at the $1 \%$ level, and $0.018 \mathrm{~g} \mathrm{l}^{-1}$ phenol red (GIBCO) was included to indicate acid formation; the medium dispensed in $10 \mathrm{ml}$ quantities/culture tube was steam sterilized. Each duplicate tube was inoculated with $50 \mu \mathrm{l}$ of a $48 \mathrm{~h}$ culture of the appropriate bacterial isolate and incubated at room temperature (ca $20^{\circ} \mathrm{C}$ ) for $7 \mathrm{~d}$ and examined daily for colour changes.

Quantitative: Marine Broth to which $10 \mathrm{~g} \mathrm{l}^{-1}$ carbohydrate (glucose, sorbitol, mannose or mannitol obtained from the Sigma Chemical Co.) had been added was dispensed in $120 \mathrm{ml}$ quantities in $250 \mathrm{ml}$ Erlenmeyer flasks and steam sterilized. The flasks were inoculated with $0.5 \mathrm{ml}$ each from $48 \mathrm{~h}$ cultures of the bacteria grown in the same medium and then incubated at $20^{\circ} \mathrm{C}$ on a platform shaker (100 ipm) using a Controlled Environment Incubator Shaker (Psycrotherm, New Brunswick Scientific Co, Edison, NJ). Samples $(20 \mathrm{ml})$ were withdrawn after 72,96 , 120 and $148 \mathrm{~h}$ for measurement of $\mathrm{pH}$. Those samples exhibiting significant acid values (i.e. reductions in the medium of 1 to $1.5 \mathrm{pH}$ units) were clarified by centrifugation and stored at $-10^{\circ} \mathrm{C}$ for later analysis.
Chemical determinations. Glucose, fructose, mannose, sorbitol, gluconic acid and gluconolactone measurements were made on culture filtrates or cell extracts with the appropriate specific enzymatic combinations as supplied by Boehringer Mannheim Canada (Laval, Quebec) and used according to the manufacturer's directions.

\section{RESULTS}

The bacteria isolated from each of the 4 Pseudonitzschia multiseries strains were subjected to a battery of tests, the results of which are reported in Table 2. All required sodium, thereby meeting the minimun qualification for designation as marine bacteria. With the aid of the scheme of Austin (1988), the studies of Hansen \& Sørheim (1991) and Bergey's Manual (Holt 1984) these characteristics, although not matching the criteria exactly, were judged to coincide closely enough to warrant assigning the isolates to the genera noted in Table 3 .

When the bacteria were grown in the presence of carbohydrates, several showed strong acid production

Table 2. Biochemical characterization of bacteria isolated from 4 Pseudo-nitzschia strains. ND: not done

\begin{tabular}{|c|c|c|c|c|c|c|c|c|c|}
\hline \multirow[t]{2}{*}{ Test } & \multicolumn{9}{|c|}{ Bacterial isolate } \\
\hline & N7 & N9 & $\mathrm{NpD} 1$ & $\mathrm{NpD} 2$ & $\mathrm{NpD} 3$ & $\mathrm{NpH} 1$ & $\mathrm{NpH} 2$ & NRO1 & $\mathrm{NRO} 2$ \\
\hline Gram stain & - & - & - & - & - & - & - & - & - \\
\hline Morphology & $\begin{array}{l}\text { Rod, } \\
\text { short } \\
\text { to coccoid }\end{array}$ & $\begin{array}{c}\text { Rods, } \\
\text { small, } \\
\text { slender }\end{array}$ & $\begin{array}{l}\text { Rods } \\
\text { short }\end{array}$ & $\begin{array}{l}\text { Rods, } \\
\text { short }\end{array}$ & $\begin{array}{l}\text { Rods, } \\
\text { large }\end{array}$ & $\begin{array}{c}\text { Rods, } \\
\text { pleomorphic }\end{array}$ & $\begin{array}{l}\text { Rods, long, can } \\
\text { join end to end } \\
\text { to form circles } \\
\text { and helices }\end{array}$ & $\begin{array}{c}\text { Rods, } \\
\text { pleomorphic }\end{array}$ & $\begin{array}{l}\text { Rods, } \\
\text { large }\end{array}$ \\
\hline \multirow{2}{*}{$\begin{array}{r}\text { Motility: wet mount } \\
\text { semi-solid }\end{array}$} & - & - & + & - & - & - & - & - & - \\
\hline & + & + & + & + & + & + & + & + & + \\
\hline O/F $(g l u)^{b}$ & NC & 0 & $\mathrm{NC}$ & $\mathrm{O}$ & Alk & Alk & NC & Alk & Alk \\
\hline Pigment (non-diffusible) & - & Yellow & - & Yellow & - & - & Yellow & - & - \\
\hline \multicolumn{10}{|l|}{ Acid from: } \\
\hline Maltose & - & + & + & - & - & - & + & - & - \\
\hline Mannose & - & + & - & - & + & - & - & - & - \\
\hline Arginine dehydrolase & - & - & - & - & + & - & - & - & - \\
\hline DNAase & - & + & + & - & - & + & + & - & - \\
\hline Gelatinase & - & - & + & - & - & - & - & - & - \\
\hline Lipase (Tween 80) & + & + & + & - & - & - & - & - & - \\
\hline Catalase & + & + & + & + & + & + & + & + & - \\
\hline Cytochrome oxidase & + & - & + & - & + & + & - & + & + \\
\hline Urease & + & + & + & + & + & + & + & - & + \\
\hline Casein hydrolysis & - & + & + & - & - & - & - & - & - \\
\hline Simmons citrate & - & - & - & - & + & - & - & - & - \\
\hline Indole & ND & ND & - & - & - & - & ND & - & ND \\
\hline Methyl red & - & + & - & - & - & - & - & - & - \\
\hline Growth at $37^{\circ} \mathrm{C}$ & + & + & + & - & + & + & + & + & + \\
\hline Requirement for $\mathrm{Na}$ & + & + & + & + & + & + & + & + & + \\
\hline Penicillin sensitiver & + & - & - & - & - & + & + & + & + \\
\hline
\end{tabular}


('Table 4A). Quantitative measurements (titration and $\mathrm{pH}$ ) confirmed that considerable quantities of acid were produced from mannose and mannitol as well as from glucose by several of the bacteria. Specific enzymatic measurements for gluconic acid/gluconolactone made on the culture filtrates showed that gluconic acid/gluconolactone was produced only in the glucose-grown cultures, and in trace amounts from certain sorbitol-grown cultures (Table 4B). The identities of the considerable quantities of acids formed in the mannose and mannitol-grown cultures were not pursued further. Interestingly, each strain of Pseudonitzschia multiseries had contributed at least 1 strain of bacteria which was a strong producer of gluconic acid/gluconolactone from glucose.

Preliminary studies using solid medium with 3 bacterial strains isolated from Pseudo-nitzschia multiseries strain $\mathrm{N}$ and designated N7, N8 and N9 showed that these bacteria did not grow with $\mathrm{NaNO}_{3}$ as the sole nitrogen source in the basal artificial seawater medium to which yeast extract and sodium acetate or glucose had been added; good growth was sustained by adding an organic nitrogen source. Growth would occur in the basal medium with proline as the nitrogen source in the absence of added growth factors, but it was slow and limited. Yeast extract added at levels between 0.01 and $0.05 \%$ produced increasingly more abundant growth in the presence of proline at 11 and $22 \mathrm{mM}$ concentrations in the medium. Proline had been selected for growth studies with both bacteria and diatoms as many species, bacterial and algal, use this amino acid for osmoregulation; proline and sorbitol are reputed to be osmoregulatory compounds in most diatoms (Kirst 1989). Proline is also central to the domoic acid structure and a possible precursor for the biosynthesis of the toxin. Growth of all 3 bacterial isolates was inhibited by a combination of glucose and glycine or sodium acetate and glycine even in the presence of yeast extract. These same bacteria did not multiply in the absence of the diatom in the artificial seawater medium prepared identically to that of the diatom medium.

When the bacterial isolates were grown in the basal medium derived from these preliminary studies to which individual amino acids were added, it was apparent that the organisms were not all equal in their capacity to grow at the expense of particular amino acids (Fig. 1). A comparison of the results reported in Table 4 with those of Fig. 1 demonstrates that bacterial isolates N7, NRO2, NpH1 and NpD1 grew well with all amino acids supplied, but did not produce much or any acid from the carbohydrates. In contrast, bacterial isolates

Table 4. Acid produced from carbohydrates by bacterial isolates. Tr: trace

\begin{tabular}{|c|c|c|c|c|c|c|c|c|c|}
\hline \multicolumn{10}{|c|}{$\begin{array}{l}\text { A. Qualitative } \\
\text { Marine broth plus } 1 \% \text { carbohydrate plus phenol red ( } 7 \mathrm{~d} \text { growth at room temperature) }\end{array}$} \\
\hline & N7 & N9 & $\mathrm{NpD} 1$ & $\mathrm{NpD} 2$ & $\mathrm{NpD} 3$ & $\begin{array}{l}\mathrm{NpH} 1 / \\
\mathrm{NpH} 3\end{array}$ & $\mathrm{NpH} 2$ & NRO1 & $\begin{array}{l}\mathrm{NRO} 2 / \\
\mathrm{NRO} 3\end{array}$ \\
\hline Glucose & $\operatorname{Tr}$ & + & - & + & - & $\mathrm{Tr}$ & + & + & $\operatorname{Tr}$ \\
\hline Sorbitol & $\operatorname{Tr}$ & - & - & - & - & $\operatorname{Tr}$ & - & - & - \\
\hline Mannose & - & + & - & + & - & - & + & - & - \\
\hline Mannitol & $\operatorname{Tr}$ & + & - & + & - & $\operatorname{Tr}$ & - & - & $\operatorname{Tr}$ \\
\hline \multicolumn{10}{|c|}{ B. Quantitative } \\
\hline \multicolumn{10}{|c|}{ Gluconic acid/gluconolactone ${ }^{a}$ in filtrates from bulk shake cultures incubated at $20^{\circ} \mathrm{C}(\mathrm{mmol})$} \\
\hline & N7 & N9 & & $\mathrm{NpD} 2$ & & $\mathrm{NpH} 3$ & $\mathrm{NpH} 2$ & NRO1 & $\mathrm{NRO} 3$ \\
\hline Glucose & & $0.121 / 0.205$ & & $0.136 / 0.100$ & & $0.161 / 0.102$ & $0.082 / 0.050$ & $0.050 / 0.012$ & $0.142 / 0.556$ \\
\hline Sorbitol & $0 / 0.013$ & & & & & $0.045 / 0.010$ & & & $0.039 / 0.004$ \\
\hline Mannose & & $0 / 0$ & & $0 / 0$ & & $0 / 0$ & $0 / 0$ & & $0 / 0$ \\
\hline Mannitol & $0 / 0$ & $0 / 0$ & & $0 / 0$ & & $0 / 0$ & & & $0 / 0$ \\
\hline
\end{tabular}



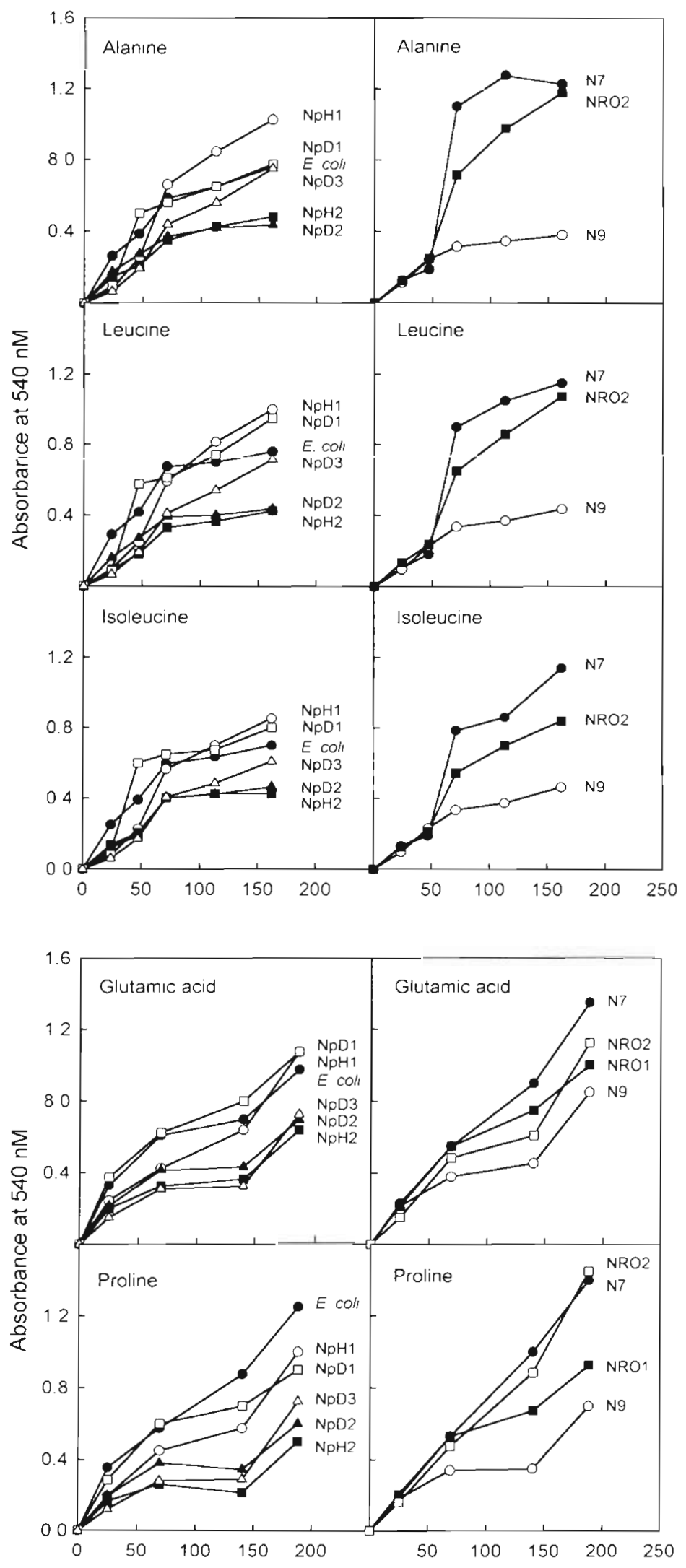

Hours
N9, NpD2, NpH2 and NRO3 were strong acid producers with carbohydrates, but N9, NpD2 and $\mathrm{NpH} 2$ lagged significantly in growth with the amino acids with the possible exception of growth with glutamic acid.

When glucose, sodium acetate, glycine or proline were added singly or in paired combinations to the normal medium for the growth of non-axenic cultures of Pseudo-nitzschia multiseries strain $\mathrm{N}$, at $10^{\circ} \mathrm{C}$, the effect was selective and striking (Figs. $2 \& 3$ ). Growth of the diatom in the presence of proline alone was increased over 4-fold. Apparently glucose and acetate exerted an inhibitory or sparing effect as the combination of proline with either of these 2 carbun sources stimuiated growin of the diatom but not to the same degree as proline alone. Glucose and acetate either alone or in combination with glycine, or glycine alone, failed to stimulate the growth of the diatom (Figs. 2 \& 3). The impact of these additives upon the growth of the bacteria in these nonaxenic cultures was roughly similar to their impact on the growth of the diatom. Combinations containing proline were markedly stimulatory, increasing bacterial numbers 1000 -fold, whereas the other combinations failed to stimulate bacterial growth or were inhibitory, i.e. acetate plus glycine (Fig. 3a). It is important to note that growth of the diatom was enhanced only where the bacterial growth was stimulated; the increase in bacterial numbers presumably occurred as a direct result of the bacterial utilization of the proline. Diatom growth (strain $\mathrm{NpH}$ ) was also affected by salinity differences (Fig. 4) where the medium at 33 ppt produced numbers 3 times greater than were observed at either the higher or lower salinity. The growth shown for the diatom in Fig. 4 is considerably higher than that shown in Figs. 2 $\& 3$ and is attributable to the use of the fastergrowing $\mathrm{NpH}$ strain at a higher temperature $\left(20^{\circ} \mathrm{C}\right)$. An examination of the diatom subsequently grown in bulk for $2 \mathrm{wk}$ at $20^{\circ} \mathrm{C}$ at these same 3 salinities showed that all possessed substantial amounts of glucose and varying amounts of sorbitol (Table 5) The considerable

Fig. 1. Growth at $20^{\circ} \mathrm{C}$ of bacteria, isolated from cultures of Pseudo-nitzschia multisenes strains, with single amino acids, $0.2 \%$, in an artificial seawater medium supplemented with yeast extract, $0.05 \%$. The Escherichia coli strain was added for reference purposes. The trials conducted in duplicate produced results which were essentially identical 


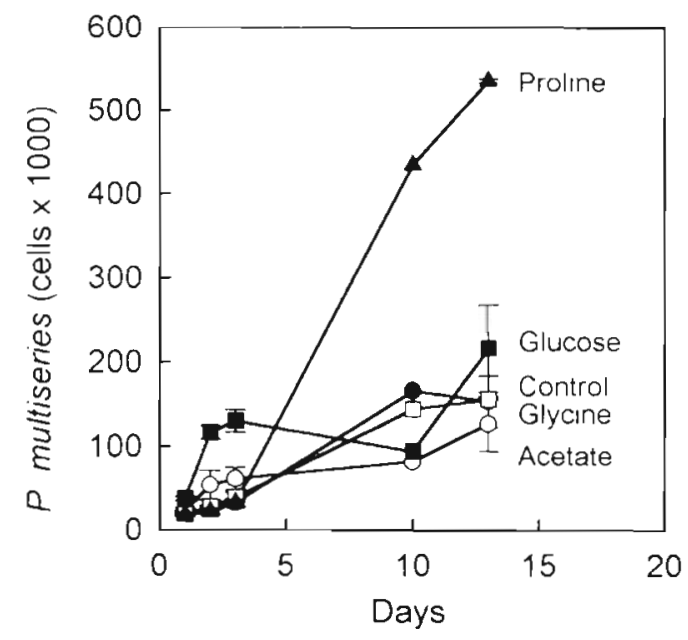

Fig. 2. Growth of Pseudo-nitzschia multiseries strain $N$ at $10^{\circ} \mathrm{C}$. The standard diatom medium was supplemented as indicated with single additives at a concentration of $22 \mathrm{mM}$; growth was measured electronically using the Coulter Counter. Error bars are $\pm \mathrm{SE}(\mathrm{n}=2)$

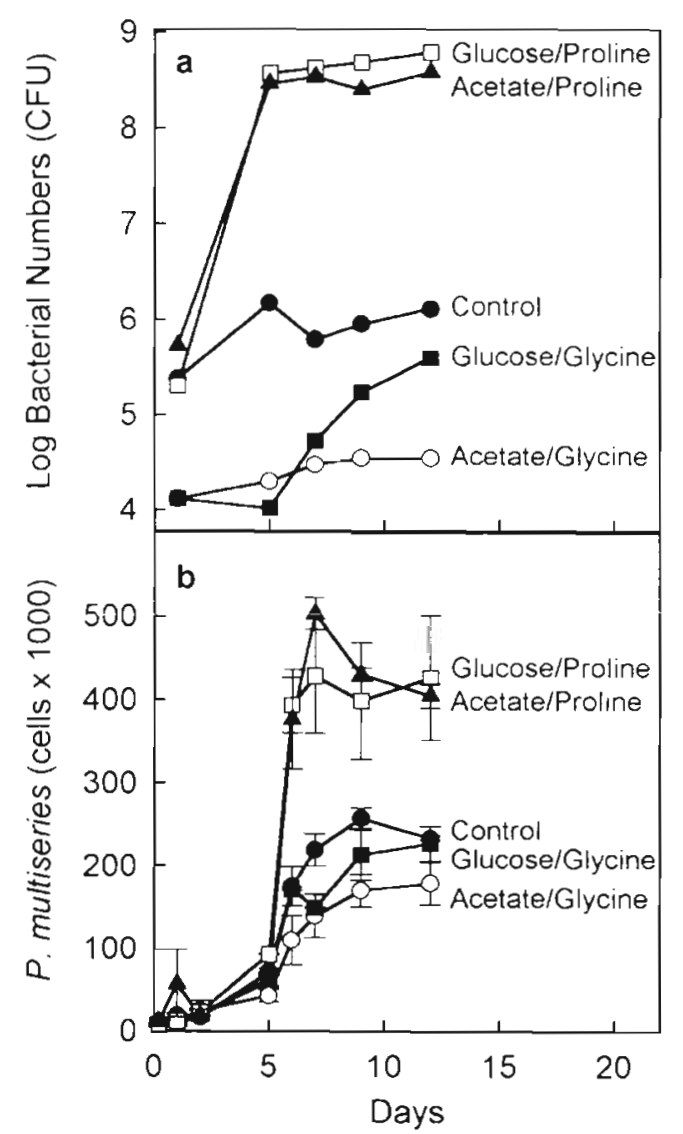

Fig. 3. Growth of Pseudo-nitzschia multiseries strain $\mathrm{N}$ and associated bacteria at $10^{\circ} \mathrm{C}$ in the standard diatom medium with paired additives $(22 \mathrm{mM}$ each) as indicated; diatom growth was measured electronically. The bacterial growth was determined by plate count. Mean $\pm S E(n=2)$ variation in sorbitol concentrations with the salinity changes suggests that of the 2 carbohydrates present, the sorbitol could have been functioning as an osmolyte in P. multiseries.

\section{DISCUSSION}

Isolation and characterization of bacteria from diatom cultures which had been allowed to stabilize showed that a discrete and characteristic suite of microorganisms persisted in an apparently beneficial microbial association. The observed benefits of the association offer evidence contrary to the conclusions of Droop \& Elson (1966) who suggested that comparable numbers of associated bacteria were too few in number to be of major importance to the diatoms. The bacterial range was quite narrow, consisting of heterotrophs judged, on the basis of the tests run, to be mainly from 2 genera, Moraxella and Alteromonas; the numbers of bacteria present in the standard diatom medium were relatively modest and constant, i.e. between 7 and 10 diatom $^{-1}$. In addition, the bacteria could be divided easily into 2 groups metabolically, one capable of producing significant amounts of acids from carbohydrates and the other growing readily at the expense of amino acids; both groups were well represented in the bacterial populations associated with each of the Pseudo-nitzschia multiseries strains. All bacteria flourished with the addition of growth factors in the form of yeast extract and an organic form of nitrogen, i.e. various amino acids. As these bacteria did not multiply in a seawater medium in the absence of

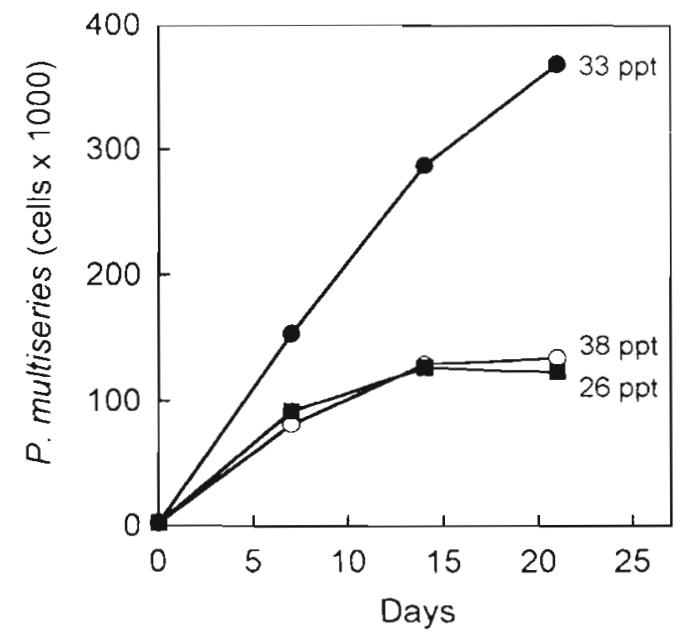

Fig. 4. Growth of Pseudo-nitzschia multiseries strain $\mathrm{NpH}$ at $20^{\circ} \mathrm{C}$ in the standard diatom medium ( $33 \mathrm{ppt}$ ) and in parallel with the same medium adjusted to $26 \mathrm{ppt}$ and $38 \mathrm{ppt}$. Growth was measured using plankton counting chambers. A second trial (results not shown) carried out with substantially higher initial inoculum values gave comparable results 
Table 5. Carbohydrate production by Pseudo-nitzschia multiseries strain $\mathrm{NpH}$

\begin{tabular}{|c|c|c|c|c|}
\hline $\begin{array}{l}\text { Salinity of } \\
\text { medium (ppt) }\end{array}$ & $\begin{array}{c}\text { Glucose } \\
\text { (mg l-1 of culture) }\end{array}$ & $\begin{array}{c}\text { Glucose } \\
\left\{\text { approx pg cell }{ }^{-1}\right\}^{\text {a }}\end{array}$ & $\begin{array}{c}\text { Sorbitol } \\
\text { (mg l-1 of culture) }\end{array}$ & $\begin{array}{c}\text { Sorbitol } \\
\left.\text { (approx. pg cell }{ }^{-1}\right)^{\circ}\end{array}$ \\
\hline 26 & 1.53 & 12.1 & 0.09 & 0.7 \\
\hline 33 & 1.59 & 5.5 & 0.109 & 038 \\
\hline 38 & 2.05 & 15.9 & 1.37 & 10.6 \\
\hline
\end{tabular}

actively growing diatoms it was concluded that the basis for growth was provided by the diatoms, i.e. presumably via releases of growth factors and compounds providing both energy and nitrogen sources. The reasons for such releases could be osmoregulation in which rapid adjustments to changing environmental conditions are made, such as the release of proline by the diatom Phaeodactylum tricornutum upon sudden reduction in salinity (Schobert 1980), releases from damaged or shocked cells, or through lysis of the host cells with concomitant release of the internal contents, or the phytoplankton exudates reported by Aaronson (1971), Larsson \& Hagström (1979), Admiraal et al. (1984), Lancelot \& Billen (1984) and Lignell (1990)

Clearly, the capacity to produce from glucose substantial amounts of gluconic acid/gluconolactone, which was released to the surrounding medium, was a feature of the bacterial populations of each Pseudonitzschia multiseries strain. Substantial amounts of acids other than gluconic acid/gluconolactone (which we did not attempt to identify) were produced from the mannose and mannitol growth substrates as shown by pronounced reductions in the $\mathrm{pH}$ values of the culture filtrates. Presumably the structure of these acids corresponded with the particular carbohydrate growth substrate.

Bacterial production of gluconic acid/gluconolactone is widespread. Its production from glucose by Pseudomonas and Phytomonas species was examined in detail by Lockwood et al. (1941) for the purpose of commercial production. They found that with submerged, aerated cultures, gluconic acid was produced in appreciable quantities (i.e. yields equal to 58 to $96 \%$ of the glucose provided) by certain species. Later, Norris \& Campbell (1949) showed that dissimilation of glucose by an oxidative organism such as Pseudomonas aeruginosa proceeded by way of gluconic and 2-ketogluconic acids with accumulation of both in the culture filtrates in the early stages of growth while some of the glucose growth substrate still remained in the medium. This pseudomonad possessed a strong system for metabolizing both gluconic and 2-ketogluconic acids; thus the compounds disappeared from older cultures following the disappearance of the glucose growth substrate. Stinson et al.
(1960) showed that gluconic acid was the main acid found in clover honey. Ruiz-Argüeso \& RodriguezNavarro (1973) argued that at least part of this acid was produced by bacteria, identified as Gluconobacter sp., which they isolated from honey during the ripening stage. These bacteria prociuced idaye amounts of gluconic acid at high glucose concentrations with aeration; they were distinguished from Pseudomonas sp. largely by their ability to grow in highly acid conditions ( $\mathrm{pH} 3$ ). Interestingly, the genera Pseudomonas, Gluconobacter and Alteromonas have much in common and the selection of distinguishing characteristics has usually been based on degrees of difference rather than absolutes. Their production of gluconic acid is a case in point.

As the studies illustrated in Figs. 2 \& 3 make clear, the benefits to be gained from the association of the bacteria with the diatoms do not solely favour the bacteria. Most of the additives (glucose, acetate or glycine) had no stimulatory effect on the growth of the diatom. When provided in combination, acetate and glycine, and to a lesser extent glucose and glycine, may even have a slightly negative effect on the growth of the diatom; one combination, acetate plus glycine, strongly inhibited the growth of bacteria associated with the diatom. Proline, added alone, produced the greatest stimulation of the growth of both diatoms and bacteria; this stimulatory effect was not enhanced by combining the proline with either glucose or acetate (Fig. 3). As many of the bacteria grew extremely well in the presence of amino acids (Fig. 1) the bacteria presumably were using the amino acids both as a source of carbon (energy and growth) and nitrogen (growth). In contrast, neither proline nor glutamic acid stimulated the growth of axenic cultures of Pseudo-nitzschia multiseries grown in continuous light in the normal diatom medium supplemented with nitrate (Osada \& Stewart 1997). Through the use of axenic cultures a number of diatoms have been shown to grow heterotrophically in the dark when supplied with a medium lacking inorganic nitrogen, e.g. Cyclotella cryptica with many amino acids (Liu \& Hellebust $1974 \mathrm{a}$, b). Similar findings were made for a wide variety of diatoms (Admiraal et al. 1984, 1986. Ming \& Stephens 1985). Subba Rao (pers. comm.) 
found that non-axenic cultures of $P$. multiseries would not only grow in continuous darkness when supplied with glutamate, but also produced domoic acid. As the growth of $P$. multiseries was enhanced only with the addition of proline in the presence of bacteria whose own growth increased massively, it must be concluded that the stimulation of $P$. multiseries growth derived from bacterial action presumably partly through supplying nitrogen in the form of ammonium ion via deamination of the amino acid to nitrogen-limited cultures. The bacterial requirement for nitrogen for cell composition can be met by $\mathrm{C}: \mathrm{N}$ ratios of $5: 1$ but the need for more carbon for energy generation and structures not containing nitrogen (e.g. lipids) suggests bacteria require a higher $\mathrm{C}: \mathrm{N}$ ratio, closer to a 10 or $12: 1 \mathrm{C}: \mathrm{N}$ ratio. These proposed ratios, in fact, tend to be confirmed by the studies and calculations of Goldman et al. (1987) and Goldman \& Dennett (1991). Thus $50 \%$ or more of the nitrogen in proline and other amino acids would be surplus to bacterial requirements and, via deamination, would be made available through a bacterially mediated route to the diatom.

That ammonium is the preferred nitrogen source for many planktonic algae has been documented repeatedly and has been reviewed comprehensively by Syrett (1981) and Flynn \& Butler (1986). Bates et al. (1993) showed that Pseudo-nitzschia multiseries grew well at the expense of ammonium, although high levels inhibited growth and enhanced domoic acid formation. A symbiotic and highly flexible relationship appears to exist in which the growth of diatoms can be enhanced greatly through the supply of specific organic materials, largely nitrogen-bearing, in the form of proteins, peptides and free amino acids which contribute to the ammonium supply through bacterial action as well as through direct use under conditions in which heterotrophy has not been considered previously. Most nitrogen made available from free amino acids, peptides and proteins to phytoplankton would, in all likelihood, be expected to result from bacterial action (Li \& Dickie 1985). The ability to use organic materials under varying growth regimes, albeit selectively and through the medium of a rapidly expandable bacterial population, confers the capacity for rapid algal growth.

The increasing enrichment, if not eutrophication, of bays and estuaries through dumping of municipal sewage, recreational activities, run-off from agricultural areas, aquaculture, and a variety of industrial discharges provides increasing amounts of both carbon and nitrogen compounds on an irregular pulsed, but continuing, basis. This could provide the foundation for algal/bacterial blooms facilitated by the flexible symbiotic systems represented by algae and their unique suites of microorganisms. This source could be more important in summer when the inorganic nitrogen is depleted. Thus, in addition to the traditional measurements of nitrate and ammonium ions made in relation to primary production in pelagic systems, it appears essential that nitrogen analyses for inshore environments should also routinely incorporate measurements of proteins, peptides and dissolved free amino acids that could be the major and continuing nitrogen sources for heterotrophic and bacterially assisted algal growth. A degree of selectivity unique to each bacterial/algal microsystem should be expected as responses to the various nutrients and the rapid minor and major changes in inshore and estuarial environments. The complexity of the metabolic interactions is underscored by the unexpected inhibition of the bacteria by the combination of glucose and glycine and also acetate and glycine, illustrating the need for detailed examination of the involvement of both single compounds and various combinations.

Salinity, especially in an inshore environment, is subject to constant minor changes and not infrequently to major changes such as those which occur following heavy rains or in northern areas because of a rapid thaw during the winter or spring. The effect upon algae can be pronounced as not all will grow equally well over a wide range of salinities (Miller \& Kamykowski 1986a, b), but rather have preferred optima interrelated with temperature. As shown in Fig. 4 this Pseudo-nitzschia multiseries strain, with an immediately previous history of growing in a medium with a salinity of around 33 ppt, had a growth optimum at $33 \mathrm{ppt}$, and grew more poorly with either a markedly increased (38 ppt) or decreased salinity (26 ppt). Jackson et al. (1992) showed through growth trials with a strain of $N$. pungens $f$. multiseries and one of $N$. f. pungens, that the $N$. pungens f. multiseries had a growth optimum ranging from 30 to 45 ppt, whereas the $N$. f. pungens grew modestly at $15 \mathrm{ppt}$ and increased its growth up to $30 \mathrm{ppt}$ after which growth fell precipitously, comparable to the results we obtained with our $P$. multiseries strain. It is interesting to note the $N$. pungens f. multiseries of Jackson et al. (1992) grew very well in salinities up to $48 \mathrm{ppt}$, a salinity well beyond the open ocean maximum of $37 \mathrm{ppt}$; taurine varied with the salinities of the media and they considered it to have an osmoregulatory role. In our trial, the concentration of sorbitol, which along with proline is often an osmolyte in diatoms (Brown \& Hellebust 1978, 1980, Kirst 1989), was reduced with the drop in the salinity. The glucose concentration in the diatom on the other hand remained substantial at all 3 salinities and was less variable (Table 5). It could be, and presumably was, a source of glucose from which the associated bacteria 
could produce the gluconic acid/gluconolactone observed by McLachlan et al. (1993).

The characteristics of bacterial/algal microsystems and their responses to various factors suggest that the circumstances imposed upon the Cardigan mussels first by the drought of 1987 followed by torrential rains initiating a massive freshwater run-off (Drinkwater \& Petrie 1988) could have heightened a Pseudo-nitzschia multiseries bloom by a reduction in salinity, a major pulse of organic and inorganic nutrients, and by mutually beneficial and selective responses by the bacteria and algae. It also suggests that studies of primary and secondary production in coastal and inshore areas must take into account events on the adjacent land masses.

The following sequence of cvents might be expected to occur in mussels feeding heavily on Pseudonitzschia multiseries: through shock, damage or lysis of the diatom there could be a release of a rich nutrient supply including substantial glucose amounts for the growth of bacteria and their production and release of appreciable quantities of gluconic acid/gluconolactone within the confining interior spaces of the mussel. Additionally, many of the diatom cells ingested have been found intact (D. J. Scarratt pers. comm.) in mussels gorged with Pseudo-nitzschia; presumably these diatom cells could be metabolically active for lengthy periods, despite the lack of light. Subba Rao (pers. comm.) found that $P$. multiseries will grow and produce domolc acid in continuous darkness when supplied with glutamate. Bates \& Richard (1996) reported that $P$. multiseries produced domoic acid during the dark portions of light:dark cycles imposed during continuous growth experiments. The gluconic acid/gluconolactone produced in situ would be expected to have a stimulatory effect on the diatom's production and release of domoic acid in the mussels, as was observed by Osada \& Stewart (1997) in P. multiseries cultures; this would add to the adverse effects already imposed upon the diatom by the confined space. Thus, in addition to whatever domoic acid was contained within the P. multiseries cells on ingestion, the domoic acid within the mussel could be increased substantially by the intact algal cells and could continue to increase as long as the algae, nutrients and bacterial systems persisted within the mussel's interior spaces. The fact that as production of domoic acid increases with the onset of adverse conditions, more is released from the algae to its surroundings makes the massive build-up of domoic acid in mussels or other molluscan shellfish, gorging for extended periods on $P$. multiseries, more understandable.

Acknowledgements. We thank Drs W. G. Harrison, W. K. W. Li and D. J Scarratt for their constructive criticism of the manuscript.

\section{LITERATURE CITED}

Aaronson S (1971) The synthesis of extracellular macromolecules and membranes by a population of the phytoflagellate Ochromonas danica. Limnol Oceanogr 16:1-9

Admiraal W. Laane RWPM, Peletier H (1984) Participation of diatoms in the amino acid cycle of coastal waters; uptake and excretion in cultures. Mar Ecol Prog Ser 15: 303-306

Admiraal W, Peletier H, Laane RWPM (1986) Nitrogen metabolism of marine planktonic diatoms; excretion, assimilation and cellular pools of free amino acids in seven species with different cell size. J Exp Mar Biol Ecol 98: $241-263$

Austin B (1982) Taxonomy of bacteria isolated from a coastal, marine fish-rearing unit. J Appl Bacteriol 53:253-268

Austin B (1988) Identification. In: Austin B (ed) Methods in aquatic bacteriology. John Wiley and Sons, Chichester, p 95-112

Bates SS, and 16 others (1989) Pennate diatom Nitzschid pungens as the primary source of domoic acid, a toxin in shellfish from eastern Prince Edward Island, Canada. Can J Fish Aquat Sci 46:1203-1215

Bates SS, Richard J (1996) Domoic acid production and cell division by Pseudo-nitzschia multiseries in relation to a light:dark cycle in silicate-limited chemostat culture. In: Penney RW (ed) Proceedings of the 5th Canadian Workshop on Harmful Marine Algae. Can Tech Report Fish Aquat Sci 2138:140-1.43

Bates SS, Worms J, Smith JC (1.993) Effects of ammonium and nitrate on growth and domoic acid production by Nitzschia pungens in batch culture. Can J Fish Aquat Sci 50:1248-1254

Bird CJ, and 37 others (1988) Identification of domoic acid as the toxic agent responsible for the P. E. I. contaminated mussel incident. Atlantic Res Lab Tech Rep 56:1-86

Brown LM, Hellebust JA (1978) Sorbitol and proline as intracellular osmotic solutes in the green alga Stichococcus bacillaris. Can J Bot 56:676-679

Brown LM, Hellebust JA (1980) The contribution of organic solutes to osmotic balance in some green and eustigmatophyte algae. J Phycol 16:265-270

Drinkwater K, Petrie B (1988) Physical oceanographic observations in the Cardigan Bay Region of Prince Edward Island 1982-1987 Can Tech Rep Hydrogr Ocean Sci 110: $1-37$

Droop MR, Elson KGR (1966) Are pelagic diatoms free from bacteria? Nature 211:1096-1097

Flynn KJ, Butler I (1986) Nitrogen sources for the growth of marine microalgae: role of dissolved free amino acids. Mar Ecol Prog Ser 34:281-304

Goldman JC, Caron DA, Dennelt MR (1987) Regulation of gross growth efficiency and ammonium regeneration in bacteria by substrate C:N ratio. Limnol Oceanogr 32 : $1239-1252$

Goldman JC, Dennett MR (1991) Ammonium regeneration and carbon utilization by marine bacteria grown on mixed substrates. Mar Biol 109:369-378

Hansen GH, Sorheim R. (1991) Improved method for phenotypical characterization of marine bacteria. I Microbiol Methods 13:231-241

Harrison PJ, Waters RE, Taylor FJR (1980) A broad spectrum. artificial seawater medium for coastal and ocean phytoplankton. J Phycol 16:28-35

Hasle GR (1995) Pseudo-nitzschia pungens and P. multiseries (Bacillanophyceae): nomenclatural history, morphology, and distribution. J Phycol 31:428-435 
Holt JG (ed) (1984) Bergey's manual of systematic bacterılogy, Vol 1 Williams \& Wilkins, Baltimore

Jackson AE, Ayer SW, Laycock MV (1992) the effect of salınity on growth and amino acid composition in the marne diatom Nitzschia pungens. Can J Bot 70:2198-2201

Kirst GO (1989) Salinity tolerance of eukaryotıc marine algae. Annu Rev Plant Physiol Plant Mol Biol 40:21-53

Lancelot C. Bullen G(1984) Activity of heterotrophic bacteria and its coupling to primary production during the spring phytoplankton bloom in the southern bight of the North Sea. Limnol Oceanogr 29:721-730

Larsson J, Hagström $\AA$ (1979) Phytoplankton exudate release as an energy source for the growth of pelagic bacteria Mar Biol 52:199-206

Li WKW, Dickie PM (1985) Metabolic inhibition of size-fractionated marine plankton radiolabeled with amino acids, glucose, bicarbonate and phosphate in the light and dark Microb Ecol 11:11-24

Lignell R (1990) Excretion of organic carbon by phytoplankton: its relation to algal biomass, primary productivity and bacterial secondary productivity in the Baltic Sea. Mar Ecol Prog Ser 68:85-99

Liu MS, Hellebust JA (1974a) Uptake of amino acids by the marine centric diatom Cyclotella cryptica. Can J Microbiol 20:1109-1118

Liu MS, Hellebust JA (1974b) Utilization of amino acids as nitrogen sources, and their effects on nitrate reductase in the marine diatom Cyclotella cryptica. Can J Microbiol 20: $1119-1125$

Lockwood LB, Tabenkin B. Ward GE (1941) The production of gluconic acid and 2-ketogluconic acid from glucose by species of Pseudomonas and Phytomonas. J Bacteriol 42:51-61

MacLeod RA (1968) On the role of inorganic ions in the physiology of marine bacteria. Adv Microbiol Sea 1:95-126

McLachlan DG, Lawrence AH, Elias L (1993) Rapid IMS analysis for the shellfish biotoxin, domoic acid. Abstract. 39th Canadian Spectroscopy Conference. Spectroscopy Society of Canada, Ottawa

Miles AA, Misra SS (1938) The estimation of the bactericidal power of the blood. J Hyg 38:732-749

Miller RL, Kamykowski DL (1986a) Effects of temperature, salinity, irradiance and diurnal periodicity on growth and photosynthesis in the diatom Nitzschia americana: lightlimited growth. J Plankton Res 8:215-228

Miller RL, Kamykowski DL (1986b) Short-term photosynthetic responses in the diatom Nitzschia americana. J Plankton Res 8:305-315

Ming L, Stephens GC (1985) Uptake of free amino acids by the diatom, Melosira mediocris. Hydrobiologia 128:187-191

Norris FC, Campbell JJR (1949) The intermediate metabolism of Pseudomonas aeruginosa. III. The application of paper chromatography to the identification of gluconic and 2 -

Responsible Subject Editor: J. T. Hollibaugh, Tiburon, California, USA ketogluconic acids, intermediates in glucose oxidation Can J Res C 27:253-261

Osada M, Marks LJ, Stewart JE (1995) Determination of domoic acid by two different versions of a competitive enzyme-linked mmunosorbent assay (ELISA). Bull Environ Contam Toxicol 54:797-804

Osada M. Stewart JE (1997) Gluconic acid/gluconolactone: physiological influences on domor acid production by bacteria associated with Pseudo-nitzschia multiseries Aquat Microb Ecol 12:203-209

Pan Y, Subba Rao DV, Mann KH, Brown RG, Pocklington R (1996) Effects of silicate limitation on the production of domoic acid, a neurotoxin, by the diatom Pseudo-nitzschia multiseries. I. Batch culture studies. Mar Ecol Prog Ser 131:225-233

Perl TM, Bedard L, Kosatsky T, Hockin JC, Todd ECD. McNutt LA, Remis RS (1990) An outbreak of toxic encephalopathy caused by eating mussels contaminated with domoic acid. N Eng J Med 322:1775-1780

Ruiz-Argüeso T, Rodriguez-Navarro A (1973) Gluconic acidproducing bacteria from honey bees and ripening honey. J Gen Microbiol 76:211-216

Schobert B (1980) Proline catabolism, relaxation of osmotic strain and membrane permeability in the diatom Phaeodactylum tricornutum. Physiol Plant 50:37-42

Stinson EB, Subers MH, Petty J, White JW (1960) The composition of honey, $V$ Separation and identification of the organic acids. Arch Biochem Biophys 89:6-12

Subba Rao DV, Dickie PM, Vass P (1988a) Toxic phytoplankton blooms in the eastern Canadian Atlantic embayments. Comm Meet Int Coun Explor Sea C.M. ICES 1988/L:28

Subba Rao DV, Quilliam MA, Pocklington R (1988b) Domoic acid - a neurotoxic amino acid produced by the marine diatom Nitzschia pungens in culture. Can J Fish Aquat Sci 45:2076-2079

Syrett PJ (1981) Nitrogen metabolism of microalgae. In: Platt $T$ (ed) Physiological bases of phytoplankton ecology. Can Bull Fish Aquat Sci 210:182-210

Todd ECD (1990) Amnesic shellfish poisoning - a new seafood toxin syndrome. In: Granéli E, Sundstrom B, Edler L. Anderson DM (eds) Toxic marine phytoplankton. Elsevier, New York, p 504-508

Todd ECD (1993) Domoic acid and amnesic shellfish poisoning - a review. J Food Prot 56:69-83

Walters GR, Plumb JA (1978) Modified oxidation/fermentation medium for use in identification of bacterial fish pathogens. J Fish Res Bd Can 35:1629-1630

Windholz M (ed) (1983) The Merck Index, 10th edn. Merck \& Co, Inc, Rahway, NJ

Wright JLC, and 18 others (1989) Identification of domoic acid, a neuroexcitatory amino acid, in toxic mussels from eastern Prince Edward Island. Can J Chem 67:481-490

Manuscript first received: March 11, 1996

Revised version accepted: March 21, 1997 